\title{
The Relationship between Perceived Stress Scale and Carotid Intima-Media Thickness Using Ultrasonography in University Students
}

\author{
Dae-Sik Kim ${ }^{1}$, Hyun-Ho Sung ${ }^{1}$, Jong-Woo Lee ${ }^{2,3}$, Eun-Kyung Cho ${ }^{1,3}$ \\ ${ }^{1}$ Department of Clinical Laboratory Science, Dongnam Health University, Suwon, Korea \\ ${ }^{2}$ Department of Neurology, Korea University Ansan Hospital, Ansan, Korea \\ ${ }^{3}$ Department of Laboratory Medicine, Graduate School of Medicine, Kangwon National University, Chuncheon, Korea
}

\section{대학생들의 스트레스 지각 정도와 경동맥 내막-중막 두께의 관계 연구}

김대식 ${ }^{1}$, 성현호 $^{1}$, 이종우 $^{2,3}$, 조은경 ${ }^{1,3}$

${ }^{1}$ 동남보건대학교 임상병리과, ${ }^{2}$ 고려대학교 안산병원 신경과, ${ }^{3}$ 강원대학교 의학과대학원 진단검사의학전공

\begin{abstract}
Carotid artery intima-media thickness (CIMT) test is a standardized ultrasound procedure that screens for and monitors atherosclerosis in a safe and non-invasive manner, even in individuals with no symptoms of heart disease. The purpose of this study was to research the relationship between CIMT, as measured by ultrasonography, and the degree of individual perceived stress. There was a total of 168 (male: 46, female: 122) university students in Suwon-si, Gyeonggi-do, Korea, without other diseases. Written informed consent was obtained from all participants. CIMT was measured in the right and left common carotid arteries $1 \mathrm{~cm}$ below the bifurcation, and internal carotid artery, using non-invasive high-resolution Medison Accuvix V20 prestige ultrasound equipment and perceived stress, was measured with the 10-item PSS (Perceived Stress Scale) questionnaire. This study indicates that PSS may be appropriate to estimate perceived stress levels and weight. Failure to control stress anxiety could lead to weight and CIMT soaring to dangerous levels, resulting in a myocardial infarction or cerebrovascular accident. There was a statistically significant difference between left CIMT $(p<0.05)$ and weight $(p<0.05)$ according to each stress classification. The results of this study suggest that the weight measurement is influenced in part by one's generalized stress levels. Future continuous studies should be conducted to test the influences of perceived stress and generalized anxiety on CIMT when these are many continuous variables.
\end{abstract}

Key words: Body mass index, Carotid intima-media thickness, Perceived stress scale

This is an Open Access article distributed under the terms of the Creative Commons Attribution Non-Commercial License (http://creativecommons.org/licenses/by-nc/4.0) which permits unrestricted non-commercial use, distribution, and reproduction in any medium, provided the original work is properly cited.

Copyright @ 2017 The Korean Society for Clinical Laboratory Science. All rights reserved.
Corresponding author: Eun-Kyung Cho Department of Clinical Laboratory Science, Dongnam Health University, 50 Cheoncheon-ro 74-gil, Jangan-gu, Suwon 16328 , Korea

Tel: 82-31-249-6419

Fax: 82-31-249-6410

E-mail: ek991012@hanmail.net

Received: July 26, 2017

Revised $1^{\text {st: }}$ : August 13, 2017

Revised $2^{\text {nd }}$ : August 16, 2017

Revised 3 ${ }^{\text {rd: }}$ August 16, 2017

Revised $4^{\text {th: }}$ : August 20, 2017

Accepted: August 21, 2017
INTRODUCTION

Excessive stress and poor coping skills can put university students at risk for mental health problems. Stress is defined as the non-specific response of the body to any demand placed upon it [1]. Stress is a non-specific 
response of the body to any demand made upon it [2,3]. Perceived stress is the feelings or thoughts that an individual has about how much stress they are under at a given point in time or over a given time period. Perceived stress incorporates feelings about the uncontrollability and unpredictability of one's life, how often one has to deal with irritating hassles, how much change is occurring in one's life and confidence in one's ability to deal with problems or difficulties. It is not measuring the types or frequencies of stressful events which have happened to a person, but rather how an individual feels about the general stressfulness of their life and their ability to handle such stress. Individuals may suffer similar negative life events but appraise the impact or severity of these to different extents as a result of factors such as personality, coping resources, and support [4]. A more precise measure of personal stress can be determined by using a variety of instruments that have been designed to help measure individual stress levels. The first of these is called "the perceived stress scale". The perceived stress scale (PSS) is a classic stress assessment instrument. The tool, while originally if developed in 1983, remains a popular choice for helping us understand how different situations affect our feelings and our perceived stress. The original PSS consists of 14 items that are purported to form a unidimensional scale of global perceived stress [5]. Although scores on the 14-item PSS tend to exhibit good reliability estimates across the literature, four of the items tend to perform poorly when evaluated using exploratory factor analysis [6]. As a result, the PSS is commonly implemented using the 10-item form [7].

Measuring carotid artery intima-media thickness (CIMT) is currently a standard diagnostic procedure in assessing cardiovascular risk (CVR) in adults. General ultrasound protocols to measure carotid intima-media thickness (CIMT) in trials rather differ. The ideal protocol combines high reproducibility with a high precision in the measurement of the rate of change in CIMT over time and with a precise estimate of a treatment effect [8]. Noninvasive assessment of CIMT is widely used in observational studies and trials as an intermediate or proxy end point for cardiovascular disease [9]. The prevalence of obesity and associated cardiometabolic disease (CMD) is increasing among world population and requires urgent attention in the form of preventive strategies. Cardiovascular reactivity is associated with carotid artery intima-media thickness as early as childhood. Excess cardiovascular responses relative to the metabolic demand during psychological stress have been proposed as a mechanism for this association [10]. However, it is not known whether excess cardiovascular responses in relation to the metabolic demand correlate with carotid artery intima-media thickness as strongly as traditionally measured cardiovascular reactivity [11]. CIMT can be used as a surrogate marker for in the study is a risk factor for cardiovascular disease [12]. However, there have been a limited number of studies focusing on the association between stress and CIMT.

This study examined differences in CIMT (as measured by ultrasonography) and degree of individual perceived stress (as measured by PSS) based on general characterizes by university students.

\section{MATERIALS AND METHODS}

\section{Sample and setting}

This study was part of a perceived stress survey, CIMT and general characterizes of university students at Suwon-si, Gyeonggi-do, Korea. In this paper, by using the survey data were completed from 2015 to December 2016. The participants in this study were 168 (male: 46 , female: 122 ) university students without the other disease. Forty-six of the subjects were male and a hundred twenty two were female. All 168 students of the CIMT (as measured by ultrasonography) were asked to complete and return a PSS questionnaire as a Researcher during study in 2015, 2016. Average age of the participants was $23.37 \pm 1.96$ at male and $21.43 \pm 2.18$ at female, as presented in Table 1 .

\section{Perceived stress scale}

The questionnaire for the study was designed by Taylor $\mathrm{JM}$, in precedent research on "Psychometric analysis of the Ten-Item Perceived Stress Scale" [7]. The subject was 
Table 1. General characteristics of subjects

\begin{tabular}{|c|c|c|c|c|}
\hline \multirow[t]{2}{*}{ Variable } & $\begin{array}{l}\text { Total } \\
\mathrm{N}=168\end{array}$ & $\begin{array}{c}\text { Male } \\
\mathrm{N}=46(27.4 \%)\end{array}$ & $\begin{array}{c}\text { Female } \\
\mathrm{N}=122(72.6 \%)\end{array}$ & \multirow[t]{2}{*}{$Z|U| W^{\dagger}, Z|F| t^{\dagger+}$} \\
\hline & \multicolumn{3}{|c|}{$\mathrm{M} \pm \mathrm{SD}$} & \\
\hline Age & $21.96 \pm 2.29$ & $23.37 \pm 1.96$ & $21.43 \pm 2.18$ & $2.81^{* *} / 1105.00 / 8608.00^{\dagger}$ \\
\hline Height $(\mathrm{cm})$ & $165.54 \pm 8.12$ & $175.60 \pm 5.69$ & $161.75 \pm 5.10$ & $1.74^{\star \star} / 230.50 / 7733.50^{\dagger}$ \\
\hline Weight (kg) & $56.54 \pm 10.56$ & $68.98 \pm 9.47$ & $51.84 \pm 6.28$ & $1.52^{\star} / 257.50 / 7760.50^{\dagger}$ \\
\hline BMI $\left(\mathrm{kg} / \mathrm{m}^{2}\right)$ & $20.50 \pm 2.59$ & $22.35 \pm 2.72$ & $19.80 \pm 2.17$ & $1.35 / 4.39 / 6.29^{\star \star}+\dagger$ \\
\hline
\end{tabular}

${ }^{*} p<0.05,{ }^{* \star} p<0.01 .{ }^{\dagger} p$-values were calculated by Kolmogorov-Smirnov, Mann-Whitney, Wilcoxon test. ${ }^{\dagger+} p$-values were calculated by t-test.

Abbreviation: BMI, body mass index; Z, Kolmogorov-Smirnov value; U, Mann-Whitney value; W, Wilcoxon value; F, Fisher distribution value; $t$, student-t-value.

assessed on selected criterion variables namely. Perceived Stress Scale (PSS; Coehn, Kamarch, \& Mermelstein, 1983) has 10 items [5]. The PSS is scored on a five-point scale, with response options ranging from $1=$ never to $5=$ =very often. The respondent made a tick $(\sqrt{ })$ on any one of the responses that fit to them best. The questionnaire to assess stress was administered on students in class room setting. The questionnaire also included the demographic profile of students. Students attempted the questionnaire after the brief description about the concept of stress. Students were restricted from discussion and were advised to attempt the questionnaire in a short notice without taking much time for thinking. The Perceived Stress Scale (PSS) is the most widely used psychological instrument for measuring the perception of stress. It is a measure of the degree to which situations in one's life are appraised as stressful. The questions in the PSS ask about feelings and thoughts during the last month. In each case, respondents are asked how often they felt a certain way. Because levels of appraised stress should be influenced by daily hassles, major events, and changes in coping resources, predictive validity of the PSS is expected to fall off rapidly after four to eight weeks. Roberti et al (2006) reported reliability estimates of 0.85 and 0.82 in a university sample for scores on the perceived helplessness and perceived self-efficacy scales, respectively [13].

\section{PERCEIVED STRESS SCALE}

(1) In the last month, how often have you been upset because of something that happened unexpectedly?

(2) In the last month, how often have you felt that you were unable to control the important things in your life?

(3) In the last month, how often have you felt nervous and "stressed"?

(4) In the last month, how often have you felt confident about your ability to handle your personal problems?

(5) In the last month, how often have you felt that things were going your way?

(6) In the last month, how often have you found that you could not cope with all the things that you had to do?

(7) In the last month, how often have you been able to control irritations in your life?

(8) In the last month, how often have you felt that you were on top of things?

(9) In the last month, how often have you been angered because of things that were outside of your control?

(10) In the last month, how often have you felt difficulties were piling up so high that you could not overcome them?

Scores around 13 are considered average (1 stage). Scores ranging from $0 \sim 13$ would be considered low stress (2 stage), scores ranging from 14 26 would be considered moderate stress ( 3 stage), and scores ranging from $27 \sim 40$ would be considered high perceived stress (4 stage). In addition, the present study analyzed the differences in general characteristics and CIMT according to the stressed and stress free groups. In addition, the present study analyzed the differences in general characteristics and 
CIMT according to the stressed and stress free groups. The two operational definition groups were that the stress free group had a PSS score of 13 (1 stage) or less, the stress group had a score of 13 or more (2 stage).

\section{Carotid ultrasonography test}

CIMT was measured in the right and left common carotid artery $1 \mathrm{~cm}$ below the bifurcation, and internal carotid artery, using non-invasive high-resolution Medison Accuvix V20 (Medison, South Korea) Prestige Ultrasound equipment. CIMT was measured by B mode ultrasound having an electric transducer with a mid-frequency of 7.5 MHz. Scans were performed on both the right and left extracranial carotid arteries by trained personnel. The CIMT values were measured in six well defined arterial segments- near wall and far wall of distal $6 \mathrm{~mm}$ of common carotid, the carotid bulb and proximal $6 \mathrm{~mm}$ of internal carotid artery of both sides. The final IMT considered was the average of the IMT values at the 12 sites examined. Study subjects were facing the left side and laid down comfortably to set the probe around the central part of the sternocleidomastoid, which is below the thyroid cartilage. The probe was manipulated vertically to show the cross section of the vein (internal jugular) and artery (common carotid) on the screen of Accuvix V20 and horizontally for the longitudinal side of the vein and artery. A dot was marked on the starting point of the dark area of the intima-media and end point of the bright area and CIMT was measured in $\mathrm{mm}$.

\section{Statistical analysis}

All statistical analyses were performed using SPSS, PC, and Version 21.0 (SPSS, Chicago, USA) program for windows. We used the Kolmogorov-Smirnov test to evaluate normal distribution. Descriptive statistics (n, minimum, maximum, mean, standard deviation) outlined the variables used within the study. Every analysis was performed on observed data. A single categorical variable is described by frequency distribution. A cross tabulation with Kolmogorov-Smirnov, Mann-Whitney were used to measure differences in two categorical variables between two groups for stressed group and stress free groups. Differences in baseline characteristics between general characteristics and personal variables were tested for significance using the t-test, ANOVA, Mann-Whitney and Wilcoxon test. In addition, the Spearman correlation analysis was performed according to the correlation. All statistical significance level was presented as proportions and mean with $95 \%$ confidence intervals (set as $p<0.05$ ).

\section{RESULTS}

\section{General characteristics of subjects}

Total participant of 168 (72.6\% females, $27.4 \%$ males) were on average $21.96 \pm 2.29$ years old at the time of the research, showing no significant difference between the male and female group. The average heights of the subject were $165.54 \pm 8.12$ and the average weight of the subjects was $56.54 \pm 10.56 \mathrm{~kg}$ that was no significant difference between male and female groups in each variable. The average BMI (body mass index) of the subjects was $20.50 \pm 2.59\left(\mathrm{~kg} / \mathrm{m}^{2}\right)$, the male showed a higher than female, they were statistically significant $(p<0.01)$. The subjects' age, height and body weight showed an irregular distribution and BMI was normal distribution (Table 1).

\section{Differences by general characteristics according to perceived stress total score}

The distribution of the perceived stress levels at the participants was tabulated as shown in Table 2A and statistically normal distribution and the mean score was 18.30 \pm 5.97. The stress classification according to the score was described in Table 2B. As a result of stress classification, 35 (20.8\%) were stress free, 27 (16.1\%) were low stress, 23 (13.7\%) were moderate stress and 83 (49.4) were high perceived stress. There was no statistically significant difference between weight and BMI results according to stress classification (Table 2B).

\section{Measurement of CIMT according to subjects}

The average (mean) rank average of males' left CIMT showed an average rank of 115.91 and the right CIMT was 
Table 2A. Perceived stress scale questionnaire results of subjects

\begin{tabular}{|c|c|c|c|c|c|c|}
\hline Questionnaire & $\begin{array}{l}\text { Never } \\
\text { N (\%) }\end{array}$ & $\begin{array}{l}\text { Almost } \\
\text { Never } \\
\text { N (\%) }\end{array}$ & $\begin{array}{l}\text { Sometimes } \\
\quad N(\%)\end{array}$ & $\begin{array}{l}\text { Fairly } \\
\text { Often } \\
\text { N (\%) }\end{array}$ & $\begin{array}{l}\text { Very } \\
\text { Often } \\
\text { N (\%) }\end{array}$ & $\begin{array}{c}\text { Overall } \\
\text { Response Score } \\
\text { [Range } 0 \sim 4] \\
\mathrm{M} \pm \mathrm{SD}\end{array}$ \\
\hline $\begin{array}{l}\text { In the last month, how often have you been upset } \\
\text { because of something that happened unexpectedly? }\end{array}$ & $17(10.1)$ & 38 (22.6) & $93(55.4)$ & $15(8.9)$ & $5(3.0)$ & $1.72 \pm 0.87$ \\
\hline $\begin{array}{l}\text { In the last month, how often have you felt that you were } \\
\text { unable to control the important things in your life? }\end{array}$ & 30 (17.9) & $70(41.7)$ & $51(30.4)$ & $14(8.3)$ & $3(1.8)$ & $1.35 \pm 0.92$ \\
\hline $\begin{array}{l}\text { In the last month, how often have you felt nervous and } \\
\text { "stressed"? }\end{array}$ & $13(7.7)$ & $18(10.7)$ & $70(41.7)$ & $49(29.2)$ & $18(10.7)$ & $2.24 \pm 1.04$ \\
\hline $\begin{array}{l}\text { In the last month, how often have you felt confident } \\
\text { about your ability to handle your personal problems? }\end{array}$ & $6(3.6)$ & 37 (22.0) & $74(44.0)$ & $43(25.6)$ & $8(4.8)$ & $2.06 \pm 0.90$ \\
\hline $\begin{array}{l}\text { In the last month, how often have you felt that things } \\
\text { were going your way? }\end{array}$ & $6(3.6)$ & 32 (19.0) & $81(48.2)$ & $42(25.0)$ & $7(4.2)$ & $2.07 \pm 0.86$ \\
\hline $\begin{array}{l}\text { In the last month, how often have you found that you } \\
\text { could not cope with all the things that you had to do? }\end{array}$ & $16(9.5)$ & $60(35.7)$ & $70(41.7)$ & 20 (11.9) & $2(1.2)$ & $1.60 \pm 0.86$ \\
\hline $\begin{array}{l}\text { In the last month, how often have you been able to } \\
\text { control irritations in your life? }\end{array}$ & $14(8.3)$ & $44(26.2)$ & $76(45.2)$ & 30 (17.9) & $4(2.4)$ & $1.80 \pm 0.91$ \\
\hline $\begin{array}{l}\text { In the last month, how often have you felt that you were } \\
\text { on top of things? }\end{array}$ & $6(3.6)$ & $18(10.7)$ & 77 (45.8) & $55(32.7)$ & $12(7.1)$ & $2.29 \pm 0.88$ \\
\hline $\begin{array}{l}\text { In the last month, how often have you been angered } \\
\text { because of things that were outside of your control? }\end{array}$ & $18(10.7)$ & $60(35.7)$ & $64(38.1)$ & $21(12.5)$ & $5(3.0)$ & $1.61 \pm 0.94$ \\
\hline $\begin{array}{l}\text { In the last month, how often have you felt difficulties } \\
\text { were piling up so high that you could not overcome } \\
\text { them? }\end{array}$ & $28(16.7)$ & $47(28.0)$ & $64(38.1)$ & 19 (11.3) & $10(6.0)$ & $1.62 \pm 1.07$ \\
\hline Total & & & & & & $18.30 \pm 5.97$ \\
\hline
\end{tabular}

Table 2B. Differences by subjects according to perceived stress score

\begin{tabular}{llcc}
\hline \multicolumn{1}{c}{ Classified stress } & $\mathrm{N}(\%)$ & Weight $(\mathrm{kg})$ & $\mathrm{BMI}\left(\mathrm{kg} / \mathrm{m}^{2}\right)$ \\
\cline { 3 - 4 } & & Mean rank & $\mathrm{M} \pm \mathrm{SD}$ \\
\hline Stress free & $35(20.8)$ & 93.73 & $20.80 \pm 2.96$ \\
Low stress & $27(16.1)$ & 89.24 & $20.35 \pm 2.05$ \\
Moderate stress. & $23(13.7)$ & 91.67 & $20.57 \pm 2.34$ \\
High perceived stress. & $83(49.4)$ & 77.08 & $20.40 \pm 2.67$ \\
Total & $168(100)$ & & $20.50 \pm 2.58$ \\
\hline
\end{tabular}

Note: No statistically significant difference by Kruskal-Wallis one-way analysis of variance and ANOVA.

108.68. Females' left CIMT showed an average rank of 73.66 and the right CIMT was 75.38. The distribution of CIMT's means rank at the participants between measures are presented in Table 3.

\section{Differences by CIMT according to perceived stress total score}

The distribution of the perceived stress levels at the participants was tabulated as shown in Table 4A and 4B. There was no statistically significant difference between left and right CIMT according to each stress classification classified into 4 stages. There was statistically significant difference between left CIMT $(p<0.05)$ and weight $(p$
Table 3. Measurement of CIMT according to subjects

\begin{tabular}{|c|c|c|c|}
\hline \multirow[t]{2}{*}{ Classified } & $\begin{array}{c}\text { Male } \\
\mathrm{N}=46 \\
(27.4 \%)\end{array}$ & $\begin{array}{c}\text { Female } \\
\mathrm{N}=122 \\
(72.6 \%)\end{array}$ & \multirow[t]{2}{*}{$Z I U / W$} \\
\hline & \multicolumn{2}{|c|}{ Mean rank } & \\
\hline Left CIMT & 115.91 & 72.66 & $4.31 / 1361.00 / 8864.00^{\star \star}$ \\
\hline Right CIMT & 108.68 & 75.38 & $4.48 / 1693.50 / 9196.50^{\star \star}$ \\
\hline
\end{tabular}

${ }^{* *} p<0.01$.

$p$-values were calculated by Kolmogorov-Smirnov, Mann-Whitney, Wilcoxon test.

Abbreviation: CIMT, carotid artery intima-media thickness; See Table 1. 
Table 4A. Differences by CIMT and general characteristics according to 4 stage perceived stress

\begin{tabular}{|c|c|c|c|c|}
\hline \multirow{2}{*}{ Classified stress } & \multirow{2}{*}{ N (\%) } & Left $\mathrm{CIMT}^{\dagger}$ & Right $\mathrm{CIMT}^{\dagger \dagger}$ & \multirow{2}{*}{$x^{2}$} \\
\hline & & \multicolumn{2}{|c|}{$\mathrm{M} \pm \mathrm{SD}$ (Mean rank) } & \\
\hline Stress free & $35(20.8)$ & $0.044 \pm 0.007(100.17)$ & $0.043 \pm 0.001(91.01)$ & $6.556^{\dagger} / 0.924^{+\dagger}$ \\
\hline Low stress & $27(16.1)$ & $0.040 \pm 0.006(75.74)$ & $0.041 \pm 0.006(81.61)$ & \\
\hline Moderate stress. & $23(13.7)$ & $0.043 \pm 0.008(90.65)$ & $0.041 \pm 0.009(84.30)$ & \\
\hline High perceived stress & $83(49.4)$ & $0.041 \pm 0.006(79.04)$ & $0.046 \pm 0.005$ & \\
\hline Total & $168(100)$ & $0.042 \pm 0.007$ & $0.043 \pm 0.005$ & \\
\hline
\end{tabular}

${ }^{\dagger}$ Left CIMT, ${ }^{\dagger+}$ Right CIMT.

No statistically significant difference by Kruskal-Wallis one-way analysis of variance.

Abbreviation: See Table 3.

Table 4B. Differences by CIMT and general characteristics according to 2 stage perceived stress

\begin{tabular}{|c|c|c|c|c|}
\hline \multirow{2}{*}{ Classified stress } & $\begin{array}{l}\text { Total } \\
\mathrm{N}=168\end{array}$ & $\begin{array}{c}\text { Stress free } \\
\mathrm{N}=35 \quad(20.8 \%)\end{array}$ & $\begin{array}{c}\text { Stressed } \\
\mathrm{N}=133(79.2 \%)\end{array}$ & \multirow{2}{*}{$Z I U I W^{\dagger}, F \mid t^{\dagger \dagger}$} \\
\hline & \multicolumn{3}{|c|}{$\mathrm{M} \pm \mathrm{SD}^{\dagger \dagger}\left(\right.$ Mean rank $\left.{ }^{\dagger}\right)$} & \\
\hline Left CIMT (Cm) & $0.042 \pm 0.007$ & $0.044 \pm 0.007(100.17)$ & $0.041 \pm 0.007(79.71)$ & $0.92 / 1779.00 * / 10690.00 *$ \\
\hline Right CIMT (Cm) & $0.043 \pm 0.005$ & $0.043 \pm 0.001$ & $0.043 \pm 0.006(82.79)$ & $0.52 / 2099.50 / 11010.50$ \\
\hline Weight (kg) & $56.54 \pm 10.50$ & $59.43 \pm 13.26(98.13)$ & $55.77 \pm 9.64(80.91)$ & $0.78 / 2004.50 / 10915.50^{*}$ \\
\hline $\mathrm{BMI}\left(\mathrm{kg} / \mathrm{m}^{2}\right)$ & $20.50 \pm 2.59$ & $20.80 \pm 2.96$ & $20.42 \pm 2.48$ & $0.81 / 0.77$ \\
\hline
\end{tabular}

${ }^{*} p<0.05,{ }^{* \star} p<0.01$. ${ }^{\dagger} p$-values were calculated by Kolmogorov-Smirnov, Mann-Whitney, Wilcoxon test. ${ }^{\dagger \dagger} p$-values were calculated by t-test.

Abbreviation: See Table 1, 3.

Table 5. Correlation of CIMT, perceived stress and general characteristics

\begin{tabular}{|c|c|c|c|c|c|}
\hline Variable & Weight (kg) & $\mathrm{BMI}\left(\mathrm{kg} / \mathrm{m}^{2}\right)$ & Left CIMT (Cm) & Right CIMT (Cm) & Perceived stress \\
\hline Weight（kg） & 1 & & & & \\
\hline BMI (kg/m2) & $0.832^{\star *}$ & 1 & & & \\
\hline Left CIMT (Cm) & $0.274^{\star \star}$ & $0.189^{\star \star}$ & 1 & & \\
\hline Right CIMT $(\mathrm{Cm})$ & $0.239^{\star \star}$ & 0.120 & $0.486^{\star *}$ & 1 & \\
\hline Perceived stress & $-0.188^{\star *}$ & -0.103 & -0.131 & -0.049 & 1 \\
\hline
\end{tabular}

${ }^{\star *} p<0.01$.

$p$-values were calculated by Spearman nonparametric correlation analysis.

Abbreviation: See Table 3.

$<0.05)$ according to each stress classification classified into 2 stages.

\section{Correlation of CIMT, perceived stress and general characteristics}

As shown in Table 5, presents the Spearman nonparametric correlations for variables. Left CIMT was positive correlated with weight $(r=0.274, p<0.01)$ and BMI $(r=0.189, p<0.01)$. Right CIMT was positive correlated with weight $(r=0.239, p<0.01)$. The perceived stress was negative correlated with weight $(\mathrm{r}=-0.188$, $p<0.01$.

\section{DISCUSSION}

The principal finding of our study is that CIMT findings correlate with the complexity of weight and BMI. Many previous studies have demonstrated the relationship between CIMT findings and the weight or BMI of obesity. Research of the CIMT as ultrasonographic marker of early atherosclerosis has been extensively studied over the present [14-17]. CIMT can be used as a surrogate marker for cardiovascular health and stress is a risk factor for cardiovascular disease. CIMT is a simple and non-invasive method of the assessment of subclinical atherosclerosis 
and has been shown to be an independent predictor of cardiovascular (CV) disease risk [18,19].

However, there have been a limited number of studies focusing on the association between stress and CIMT. The goal of this study was to explore the association between perceived stress and CIMT in a university student. The subjects' age, height and body weight showed an irregular distribution $(p<0.01)$ and BMI was normal distribution. However, the relationship between CIMT and the complexity of perceived stress has not been investigated. As a result of stress classification, 35 (20.8\%) were stress free, 27 (16.1\%) were low stress, $23(13.7 \%)$ were moderate stress and 83 (49.4) were high perceived stress. There was no statistically significant difference between weight and BMI results according to stress classification. There was statistically significant difference between left CIMT $(p<0.05)$ and weight $(p<0.05)$ according to each stress classification classified into 2 stages. Stress can cause several changes in the individual's body that can lead to the development of chronic diseases such as high blood pressure [20]. Raised blood pressure (BP) is the leading cause of death and the second leading cause of disability worldwide [21]. The damage caused by raised BP is mainly through its effects on cardiovascular disease (CVD) (strokes, heart attacks, heart failure) and kidney disease. With no plans on how to cope with stress, many resort to eating practices that become habitual, while increasing the risk for obesity because many foods that appear to reduce stress are addictive [22]. The weight of the evidence that we were able to identify suggests that stress results in an increased risk of atherosclerosis, assessed CIMT. Cardiovascular diseases are the leading cause of death in developed countries. They are also a major problem, not only as far as coronary artery disease $(\mathrm{CAD})$ is concerned but also in terms of stroke, the incidence of which is among the highest in the world. This study is based on the need to find a perceived stress and CIMT for assessing relation the obesity in students and examined differences in obesity and CIMT as measured by ultrasonography based on degree of individual perceived stress by university students. The prevalence of obesity and associated cardiometabolic disease (CMD) is increasing among world population and requires urgent attention in the form of preventive strategies. CIMT can be used as a surrogate marker for cardiovascular health and stress is a risk factor for cardiovascular disease. However, there have been a limited number of studies focusing on the association between stress and CIMT. Therefore, a study was conducted to measure CIMT in stressor from these conditions (control group), who were classified according to gender, BMI and stress. The results suggest caution in the management of stress with obesity as stress-induced cardiovascular diseases together with therapeutic doses may lead to coronary artery disease. In fact, in developed countries, the most common cardiovascular disease is $\mathrm{CAD}$, which is also the leading. This study indicates that the PSS is appropriate for estimating the perceived stress levels. Failure to control anxiety could lead to CIMT soaring to dangerous levels resulting in a myocardial infarction and/or cerebrovascular accident. Failure to control stress and anxiety could lead to CIMT soaring to dangerous levels resulting in a myocardial infarction and/or cerebrovascular accident [23]. Individuals should engage in healthy lifestyle practices that lower stress and anxiety levels to decrease the chances of cardiovascular disease. It is recommended that those in high-stress job group increase physical activity and reduce job insecurity to improve health [24]. In this study, the results of the left CIMT were generalized to weight, but the results of the PSS were reversed. The limitation of this study was that the age and the number of samples with low stress were the problem. Conclusion, the results of this study suggest that the weight measurement is influenced in part by one's generalized. Futures continuous studies should be conducted to variety test the influences of perceived stress and generalized anxiety on CIMT when these are many continuous variables.

\section{요 약}

경동맥 내막-중막 두께(CIMT) 검사는 심장 질환의 증상이 없는 환자에서도 안전하고 비 침습적으로 죽상경화증을 검사하 고 모니터 할 수 있는 표준화 된 초음파 절차이다. 본 연구의 목 
적은 초음파로 측정 한 경동맥 내막-중막 두께와 환자의 스트레 스 정도를 측정하는 것이었다. 연구 대상자는 경기도 수원시에 있는 기타 질환이 없는 대학생 168 명(남자 46 명, 여자 122 명) 이었다. 이 연구에서 참가자들의 연구 참여는 문서를 통하여 개 인적으로 동의를 받았다. 경동맥 내막-중막 두께는 비 침습성 고 해상도 Medison Accuvix V20 초음파 장비를 사용하여 분기 점 아래 $1 \mathrm{~cm}$ 의 좌우 총경동맥에서 측정되었고, 스트레스 인지 정도는 10 가지 항목의 PSS (Perceived Stress Scale)설문지를 이용하였다. 이 연구는 PSS가 인지된 스트레스 수준과 체중을 추정하는데 적절함을 나타냈다. 스트레스 유무에 따라 좌측 CIMT와 체중 간에 통계적으로 유의 한 차이가 있었다 $(p<0.05)$. 이 연구의 결과는 체중 측정이 부분적으로는 일반화 된 스트레 스에 영향을 받는다는 것을 시사합니다. CIMT에 대한 인지된 스트레스와 일반화 된 불안의 영향을 테스트하기 위해서는 다양 한 연구가 지속적으로 이루어져야 할 것으로 사료된다.

Acknowledgements: This study was financially supported by Dongnam Health University.

\section{Funding: None}

Conflict of interest: None

\section{REFERENCES}

1. Muthuvelayutham C, Mohanasundaram H. A study on the impact of occupational stress among teachers on job satisfaction and job involvement-an empirical study. Eur J Soc. 2012; 30(2):339-51.

2. Koloski NA, Talley NJ, Boyce PM. Predictors of health care seeking for irritable bowel syndrome and nonulcer dyspepsia: A critical review of the literature on symptom and psychosocial factors. Am J Gastroenterol. 2001;96(5):1340.

3. Mayer EA, Emeran A. The neurobiology of stress and gastrointestinal diseases. Am J Gastroenterol. 2000;47(6):861-869.

4. Gellman MD, Turner JR. Encyclopedia of Behavioral Medicine. Washington DC, USA: Springer; 2013. p1453-1454.

5. Cohen S, Kamarck T, Mermelstein R. A global measure of perceived stress. J Health Soc Behav. 1983;24(4):385-396.

6. Cohen S, Denise JD. Who's stressed? Distributions of psychological stress in the United States in probability samples from 1983, 2006, and 2009. J Community Appl Soc Psychol. 2012; 42(6):1320-1334.

7. Taylor JM. Psychometric analysis of the ten-item perceived stress scale. Psychol Assess. 2015;27(1):90-101.

8. Dogan S, Duivenvoorden R, Grobbee DE, Kastelein JJ, Shear CL, Evans GW, et al. Ultrasound protocols to measure carotid intima-media thickness in trials; comparison of reproducibility, rate of progression, and effect of intervention in subjects with familial hypercholesterolemia and subjects with mixed dyslipidemia. Ann Med. 2010;42(6):447-464.

9. Bots ML, Hoes AW, Koudstaal PJ, Hofman A, Grobbee DE. Common carotid intima-media thickness and risk of stroke and myocardial infarction. Circulation. 1997; 96(5):1432-1437.

10. Reinehr T, Kiess W, De Sousa G, Stoffel-Wagner B, Wunsch R. Intima media thickness in childhood obesity: relations to inflammatory marker, glucose metabolism, and blood pressure. Metabolism. 2006;55(1):113-118.

11. Lambiase MJ, Joan D, James NR. Metabolic and cardiovascular adjustments during psychological stress and carotid artery intima-media thickness in youth. Physiol Behav. 2012;105(5): 1140-1147.

12. Xu W, Hang J, Cao T, Shi R, Zeng W, Deng Y, , et al. Job stress and carotid intima-media thickness in Chinese workers. J Occup Health. 2010;52(5):257-62.

13. Roberti JW, Harrington LN, Storch EA. Further psychometric support for the 10-item version of the perceived stress scale. J Coll Couns. 2006;9(2):135-147.

14. Lo J, Dolan SE, Kanter JR, Hemphill LC, Connelly JM, Lees RS, Grinspoon, SK. Effects of obesity, body composition, and adiponectin on carotid intimamedia thickness in healthy women. J Clin Endocrinol Metab. 2006;91(5):1677-1682.

15. Kotsis VT, Stabouli SV, Papamichael CM, Zakopoulos NA. Impact of obesity in intima media thickness of carotid arteries. Obesity. 2006;14(10):1708-1715.

16. Freedman DS, Dietz WH, Tang R, Mensah GA, Bond MG, Urbina EM, Berenson GS. The relation of obesity throughout life to carotid intima-media thickness in adulthood: the Bogalusa Heart Study. Int J Obes Relat Metab Disord. 2004;28(1):159-66

17. Tounian P, Aggoun Y, Dubern B, Varille V, Guy-Grand B, Sidi D, et al. Presence of increased stiffness of the common carotid artery and endothelial dysfunction in severely obese children : a prospective study. Lancet 2001;358(9291):1400-1404.

18. Naghavi M, Libby P, Falk E, Casscells SW, Litovsky S, Rumberger J, et al. From vulnerable plaque to vulnerable patient: a call for new definitions and risk assessment strategies: Part I. Circulation. 2003;108(14):1664-1672.

19. Naghavi M, Libby P, Falk E, Casscells SW, Litovsky S, Rumberger J, et al. From vulnerable plaque to vulnerable patient: a call for new definitions and risk assessment strategies: Part II. Circulation. 2003;108(15):1772-1778.

20. Rosenthal T, Alter A. Occupational stress and hypertension. JASH. 2012;6(1):2-22.

21. Lawes CM, Vander Hoorn S, Rodgers A. Global burden of blood-pressure-related disease, 2001. Lancet. 2008;371(9623): $1513-1518$.

22. Kobayashi D, Takahashi O, Deshpande GA, Shimbo T, Fukui T. Association between weight gain, obesity, and sleep duration: a largescale 3-year cohort study. Sleep Breath. 2012;16(3):829833.

23. Kim MY, Kim HS, Kim SY. Association of carotid artery intima-media thickness and cardiovascular risk factors in adult. J Radiol Sci Technol. 2013; 36(1):25-30.

24. So JK, Kim JS, Lee YH, Kim DJ, Park CE. Investigation of Subcategories according to the Level of Job Stress in Medical Technologist. Korean J Clin Lab Sci. 2017;49(1):48-54. 